\title{
The Poor Agricultural System in Africa, Who Is to Blame?
}

\author{
Eileen Bogweh Nchanji ${ }^{*}{ }^{(\mathbb{D}}$, Yvonne Kiki Nchanji $^{2}$ (), Ivan Adolwa ${ }^{3}$ \\ ${ }^{1}$ International Center for Tropical Agriculture, Nairobi, Kenya \\ ${ }^{2}$ University of Eastern Finland, Joensuu, Finland \\ ${ }^{3}$ African Plant Nutrition Institute, Nairobi, Kenya \\ Email: *e.nchanji@cgiar.org
}

How to cite this paper: Nchanji, E.B. Nchanji, Y.K. and Adolwa, I. (2021) The Poor Agricultural System in Africa, Who Is to Blame?. Agricultural Sciences, 12, 1375-1403. https://doi.org/10.4236/as.2021.1212088

Received: September 22, 2021

Accepted: December 10, 2021

Published: December 13, 2021

Copyright (c) 2021 by author(s) and Scientific Research Publishing Inc. This work is licensed under the Creative Commons Attribution International License (CC BY 4.0).

http://creativecommons.org/licenses/by/4.0/

\begin{abstract}
Although agriculture is the backbone of the African economy, it has faced considerable challenges in the past sixty years. Africa has moved from being a self-sufficiency continent before the 1960s, to net food importers, with a handful of countries facing severe food shortages from drought, desertification, climate change and wars. In this article, we use the case of Northern Ghana to explore some of the salient dynamics that have resulted in the current crisis in the African agricultural sector over time. Using historical and contemporary evidence gathered from Northern Ghana during several field trips from 2013 to 2015, we argue that practices adopted as a result of colonial influence in combination with socio-economic and biophysical factors and ineffective economic policies have contributed immensely to the poor state of agriculture in Africa. Note should be taken that most of these economic policies have origins from the Structural Adjustment Policies and the Poverty Reduction Strategy Papers. We conclude that our agricultural systems can be improved if policies are inclusive, equitable and sustainable and also if there are synergies between international or government organisations implementing agricultural projects over time and space.
\end{abstract}

\section{Keywords}

Agricultural Policies, Green Revolution, Agricultural Transformation, Vegetable Farming, Northern Ghana

\section{Introduction}

The agricultural system in Africa has always been predominantly subsistence, even with the introduction of many technological packages to revolution arise this sector during colonial rule [1]. After the independence of many African 
states, a lot has been done to transform agriculture from a subsistence activity to an industrialised one with little or no success-as the African green revolution failed [2]. The Structural Adjustment Policies (SAP) were initiated in the 1980's when the economies of many African countries took the turn for the worst. SAP aimed at alleviating poverty and bringing about economic growth. Countries who took up SAP were expected to withdraw government subsidies, reduce state expenditure on social services on housing, health and education, privatise state enterprises and create an enabling environment for foreign investments. According to critics, the SAP did not achieve its goal but worsened the economies of most of the countries which adopted it [3] [4]. Fatton [5] argued that SAP was a hindrance rather than a form of assistance as "global capitalist" economies exploited and directed African states for example they provided loans and dictated the conditions for repayment. Thus the "inevitable" implementation of SAP was only true insofar as "resistance was not a viable option" [6].

In Ghana, even though, gross national investment and industrial capacity of the country increased, a majority of Ghanaians remained poor as the country incurred more debts than it could pay. Regional inequality was never addressed, and the poverty situation worsened [7]. The Poverty Reduction Strategy Papers (PRSP) were introduced in the $19^{\text {th }}$ century to solve the problems created by the SAP; it was a poverty reduction framework committed and devoted to poverty reduction at all levels [8] [9]. This strategy was also imperative if Ghana wanted to benefit from the Highly Indebted Poor Countries (HIPC) Fund-concessional credits and grants of about US $\$ 3.7$ billion over a 20 -year period. The PRSP was based on five principles-it had to be owned by the country, should be result-oriented, holistic in nature, participatory and have long term effects; these principles were arrived at as a result of earlier criticisms of the SAP. Other agricultural strategies like the Accelerated Agricultural Growth Development Strategy (AAGDS) - to reduce poverty and improve human welfare and the International Fund for Agricultural Development (IFAD) initiatives in the Northern Region had to be made consistent with the PRSPs. The PRSP was required to outline its anti-poverty strategy and explain how donor funding-HIPC would be used to reduce poverty.

Critics such as Domfeh and Bawole [10], Carr [11] and Whitfield [8] have termed the Ghana PRSP as old wine in a new bottle, where an aid regime has been promoted and encouraged instead of a trade regime which can boost private investment and growth in the agricultural sector. Over the last decade, Ghana has met the Comprehensive African Agricultural Development Programme (CAADP) targets, but regional disparities still exist in poverty levels and agricultural productivity [12]. To boost investments and productivity, intra-African trade and regional agri-food value chains, the Economic Community of West African States (ECOWAS) has also put in place regional agricultural policies of which Ghana is a signatory, but these policies seem not be solving the agricultural problems in the country. This article will show what we have been 
doing wrong and are still doing wrong and propose what we need to do to move forward. The evolving agricultural system in the Northern region will be assessed with emphasis on changes due to the socio-economic and political interaction of different material and social cultures from pre to post colonial era.

This work is framed around the notion of entangled history adopted from the works of Weiss [13], where the interactions of different "social spaces" are studied to understand production, distribution and consumption patterns which overlap over time. This essay will examine the history of the Dagomba people who make up the Northern Region and throw some light on how their political and socio-economic environment shaped their agricultural practices and system. It also explains how the agricultural activities of the Dagomba people have been shaped by the different land and agricultural policies enacted and carried out in pre-colonial, colonial and post-colonial times. Finally, why vegetable agriculture has become an integral economic activity of the Dagomba people especially with increasing urbanisation in the city of Tamale.

\section{Material and Methods}

\subsection{Study Site}

Blench and Dendo [14] estimated the surface area of the Northern Region as 70,384 sq.km. It is the largest region in Ghana. It comprises about $41 \%$ of the total land area in Ghana with headquarters in the Tamale Metropolis. Its population density is noted to be the lowest in the country. Rain-fed agriculture is predominant in this region as opposed to irrigated farming which even though present in the country, takes place in less than $2 \%$ of the total cultivated area [14] [15]. The primary economic activity of the Dagomba's is agriculture, which employs more than $70 \%$ of the active population [16]. Most importantly about $90.5 \%$ of households in the Northern region practice crop farming compared to other forms of agriculture [16].

Interviews with key informants revealed that the Dagbon people have always relied on their farming skills as a source of income to provide and sustain their families. When the colonial administrators settled in Tamale as their headquarters, few Dagomba's were interested in administrative jobs like clerks and teachers. As in the Dagomba culture, a man was defined according to his capacity to provide food for his family from his field, and white collar jobs were considered "activities of the weak". Agriculture is an ancient activity which constitutes the backbone of the Dagomba identity. Tamale has become an urban agricultural city, with weaknesses not so different from the general agricultural system, but there are opportunities which if harnessed would make the system more sustainable and inclusive.

The above narrative gives us a glimpse into the socio-political life of the Dagbon people, which is embedded in their origin. These historical recollections are echoed by current writers like Imam [17] and Mahama [18] who painted them as warriors, skilled hunters, and great agriculturalist. They are organised in cen- 
tralised states with a patriarchal system of inheritance, where women are not included in the decision making of the state.

\subsection{Methods}

The agricultural activities of the Dagomba people from the pre-colonial era to present date were extracted from secondary sources, archival data and oral history collected by anthropologists and historians who first visited these people. Even though oral history is considered problematic due to its sources and credence, it gives a clear picture of the past socio-political relationship of people [19]. Also, primary data was collected from farmers, government officials, non-governmental organisations and traditional rulers through 101 key informant interviews, 35 focus group discussions, informal discussions and participant observations on fields especially from September 2013 to March 2015. The questions addressed in these interviews and discussions focused on; pre-colonial and existing agricultural policies, evolving agricultural practices with a focus on urban vegetable farming and social norms which condition farm activities and practices.

The key informant interviews purposively targeted key stakeholders who are knowledgeable about the subject of discussion and have experiences from faming during the pre to post colonial era. The information from key informant interviews was triangulated with information from focus group discussions disaggregated by gender and occupation. These qualitative methods provided us with indepth knowledge of what activities took place, how and why it did. Combined with achival data and secondary literature we had a more holistic picture of the agricultural system in Northern Ghana and why it has not changed much. The paper is part of my doctoral work. The aim of the study was clearly explained to all respondents. Permission was sought verbally before data collection. Respondents were informed of their right to stop the interview or completely refuse to participate in the research. Few respondents opted out during this study.

\section{Result and Discussion}

The agricultural system in the Northern region has evolved with resultant changes in the production, distribution and consumption patterns of the people. The different agricultural policies have shaped and are still shaping farmers practice within their socio-economic and political environment. Changes in the agricultural activities of the Dagomba people will be considered at different time scales from pre-colonial times to date in relation to changing agricultural policies and the social reality of the people.

\subsection{Pre-Colonial Era}

In pre-colonial times, agricultural activities of the Dagomba's were captured by historians and anthropologist through tales and participant observation. Cardinall and Tamakloe [20] argued that, even though most traditional tales and his- 
tory in Africa are regarded as superstition, they are believed to be accurate by the people who live it daily and to whom it is considered perfectly natural. This assertion he puts in opposition to tales in European peasantry societies which are half believed and not assumed to be natural occurrences. Talton [21] also emphasised the importance of historical recollections in defining the customs and traditions of people, their socio-political structure and how they construct their identity and access to and control over different resources. Through tales of human interactions with the gods, we see a clear picture of the type of agricultural system that existed before colonialism [20] influenced by religion and culture and constructed around the socio-economic and political environment; the people lived in. An example is the tale of Edubiaku the wise child, which describes how man received seeds as a gift from the gods to plant far afield and later around the living abode.

Blench and Dendo [14] corroborated the idea of farming far away from the living quarters, or the compound when he talks about the practice of bush farming in the Northern parts of Ghana. He explains that many fields were cultivated far from the living abode-about 4 to $10 \mathrm{~km}$. From the different tales written in Cardinall and Tamakloe [20], we deciphered that due to the destruction of crops far from the compound by animals, the guard of the gods advised humans to sow their seeds close to their compounds. Now referred to as backyard farms or compound farms which are considered an ancient activity that existed all over the world and still practised today [22].

According to Kranjac-Berisavljevic and Gandaa [23], 75\% of farmers in the North cultivate yams; this region constitutes the "yam zone" which runs from Cameroon to Ivory Coast supplying about 90\% of world's yams each year-about 33.7 million tonnes [24]. Yam farming is not just an economic activity, but it is embedded in the culture and traditions of the people. During communal farming, yam seedlings are exchanged as a sign to appease the gods; these seedlings are believed to possess blessings from the gods and manifest in high yields [23]. Apart from yams, cereals like sorghum, millet and guinea corn are also cultivated in this region, and livestock rearing takes place [24]. These activities are reflected in the stories narrated by [20] for example the cob of maize and a hundred slaves. In this tale, the Dagomba people were visited by a god who lost his son during his sojourn with them. To sympathise with him, they offered him abundant maize as compensation. This tale shows the hospitality of the Dagomba people showcasing one of their main staple crops and economic activities already practised at that time. These agricultural activities were mainly for subsistence, where surpluses were sold to get other needed goods in the regional and local markets especially along the Salaga slave market route [25].

The main ways of cultivating land in the pre-colonial era were through bush fallowing and shifting cultivation explained by Blench [26]. He stated that bush farms were cultivated for three to four years and when it showed signs of low productivity this land was left to fallow and another area chosen for farming. To 
be able to access new lands for farming one gave a token to the chief or the tindana of the village. This token often came in the form of a kola nut after which a ritual is performed to bless the land. Then the new owner gets "use right" to the land, which he can pass on from generation to another.

The Linguist-the spokesman of the Zagyuri chief, during an interview, stated that during the pre-colonial times, when a person requested for a piece of land for farming, physical objects like trees and stones were used as boundary markers. A mark was usually put on these objects to indicate where a land boundary strated or ended. This was a way to make the land legible and easy to manage by the chief. It was also an act of grounding claims. Access to land was not a problem as land was in abundance-strangers were also given lands for farming and housing with use rights. When a stranger decided to leave an area of land acquired traditionally, he forfeits all investments made on the land. He was not authorised to sell the land or the investments on it because the land was not sold to him. He was expected to give the land back to the chief who gave him use rights over it. In the case of indigenes, the use rights on the land can be passed on from one generation to another, or if the indigene wants to leave the area, he can give the land to another indigene or relative after the chief has been informed and agrees to these new arrangements.

Land access was through the men in the households and women could only get access to land through them. This practice solidified the status of men as the decision makers in the community and society as a whole. Rituals and libations were poured on land for cleansing, an activity performed by the traditional institutions which constituted of mostly men. These rituals and sacrifices transformed the land into a spiritual being, through which one communicates with his ancestors. The above explaination is one of the reasons why lands are allocated and not sold in this region. This tradition is now dying out as lands are now being "sold" by chiefs for personal gain especially with the increasing value of land due to urbanisation [27].

Farmers in Sangani during a focus group discussion said this vegetable site is a sacred shrine. Their ancestors have been performing rituals and sacrifices to their gods, before the coming of the Europeans. There is a natural spring on this land and a big kapok tree (Ceiba pentandra), where these rituals take place. An animal is killed by the spring water and later grilled, and eaten under the kapok tree, as no sacrificial meat had to leave the sacred grounds. When the rains do not come as expected, an ancestral stone will be taken out of the spring water amidst animal sacrifices, and the gods will respond by sending rain so the ancestral stone can return to the water where it belongs.

Here we see how tradition in the form of sacrifices throughout the year "promote agriculture and the harmony of the local group" these rituals strengthens the "well-being of the community and reaffirm the solidarity of lineages" [26]. This traditional activity of performing rituals also became an important element in promoting livestock rearing, as animals were always needed for sacrifices [26]. 
Women were ascribed specific agricultural and social roles in the household and community [28]. A woman was expected to cultivate vegetables and legumes at the fringes of the family's bush farm. They had a traditional responsibility to "provide the ingredients for preparing the soup or stew which goes with food prepared from grains supplied by the husband" [29]. A woman who could not provide soup for her household was labelled useless and sometimes called a "witch". This is because food provisioning responsibilities were taken seriously in the society and community and one's failure was considered an act of wickedness. This complementary division of labour according to [29] might have originated when men were hunters. According to Goody and Buckley [30] "if at the hunting stage women were the ones who collected vegetable produce, they would tend to be the ones concerned with cultivating the domestic varieties of these plants; just as men who had formerly been concerned with hunting wild animals would tend to take over the husbandry of domestic livestock."

Musah [31] and Tengan [32] detailed the importance of the traditional maternity leave, women took during the birth of the first and second child in their natal homes as part of their traditional provisioning roles. During this period, they were expected to stay with their parents till their children started walking. They could work on farms belonging to their parents or natal family. She was expected to accumulate her "bride wealth" which she will later take to their husband household, to continue life officially as the "cooking wife." This accumulated wealth exclusively belonged to the woman. This wealth was in the form of money or material objects of value that the women had been given or had bought. Men created control mechanisms to regulate the wealth of women through the use of labels such as "witches." For example, if a woman shows more economic prowess than her husband and acquires a piece of land or building without his concert, she may be labelled a witch by her husband. When this happened, the woman was abandoned by her family and the community to her own devices. This was a disgrace to the woman, and her family as the pride of a woman laid with her husband and what he said about her to others [31].

Focus group discussions with farmers revealed that crop farming was done mainly through human physical labour, from clearing the land, sowing, and harvesting. Marketing was mainly done by women or children, with goods carried on their heads and sold in the villages and national markets depending on the goods to be sold. Men participated more in clearing the fields and sowing while harvesting was mainly a shared activity. The "traditional food farming in Ghana is family labour inclined-where members of the family operate as a production unit to cultivate small scattered fields with simple like tools-cutlasses and hoes-to, cater mainly for their food needs" [29]. The family in the Dagomba context from interviews and participant observation includes everyone that makes up a compound.

A compound as depicted in Figure 1 is usually made up of the household head, his wives and children, his brothers, their wives and children and maybe 


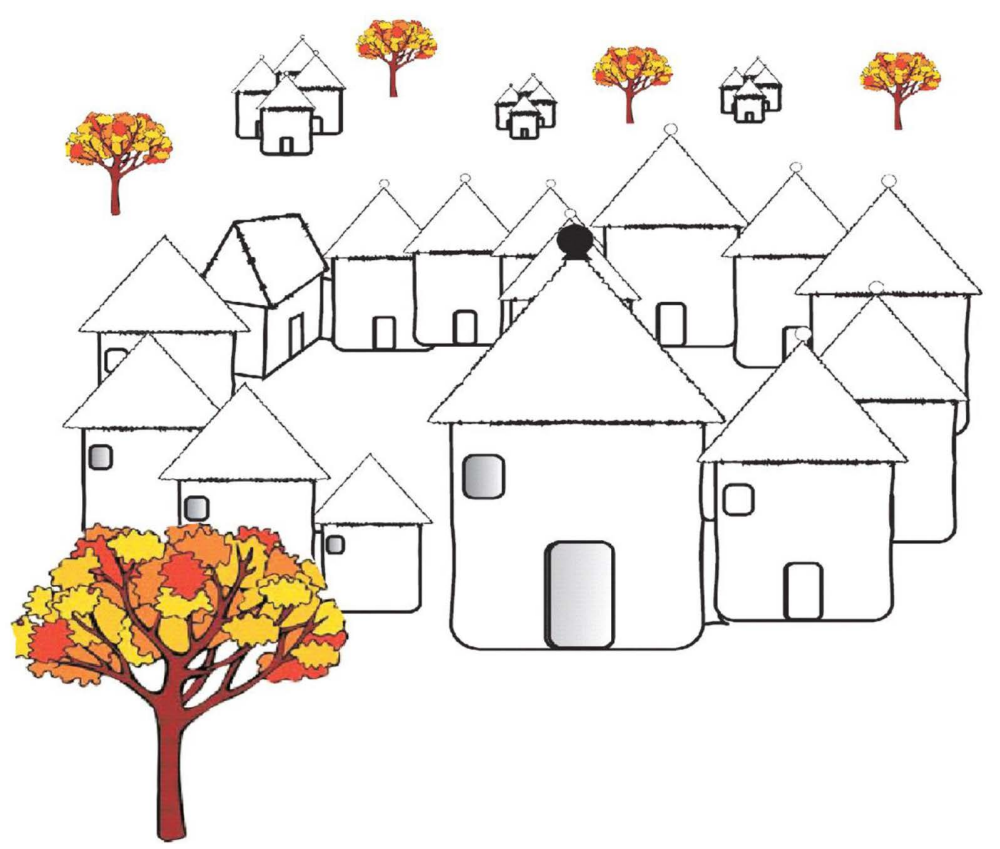

Figure 1. Drawing of a Dagomba compound with the different traditional houses. Source: Author's construct, with assistant Mr Baako, 2014.

his parents. Everyone in the compound is considered a family as they usually eat from the same pot. The women each have a day or week to prepare food for the whole compound. The main entrance is usually meant to entertain guest. The household head's house is close to the entrance and that of his last wife. The rest of the family is found in the middle of the compound. Food and livestock are stored close to the entrance on the left side of the compound. The power dynamics are evident with the household head building taking a central stage to all activities in the compound. The size of the farm usually reflects the availability of family labour. The Dagomba families are large and range from 6 - 20 people. Intercropping and mono-cropping were both practised by farmers. Cereals and rice were usually planted on the same land, and never rotated with other crops. Legumes, cereals, and vegetables were intercropped in the compound or backyard farms.

Dickson [33] detailed the farming process in this quote "preparation of land for sowing began with burning the bush, after which the charred bush was slashed with cutlasses and thrown, together with tree trunk...”. When crops get into the barn especially cereals, the men are in charge of giving it out to their different wives or sister-in-laws assigned to cook. A woman cannot help herself to cereals in the barn without permission from the household head.

Other forms of labour existed apart from family labour like communal labour. It involves people working communally without monetary rewards on the farms of another. This communal form of labour was organised amongst groups of families, friends or lineages. The host farmer was expected to provide food and drinks like pito (which is made of fermented millet and brewed for some hours) 
for all during the period they worked in his field. This system of farming was rotatory and was sometimes extended to the sick or very old in the community, who at one time was part of this scheme [29] [33].

Chiefs also relied on community labour for their large farms [29]. This is seen clearly in Fortes and Fortes [34] ethnographic data which stated that chiefs and headmen had food even in hard times due to community labour. This is further reflected in Weiss [13] diaries, where locust invasion destruction was less on the farms of the chiefs than the villagers as the chiefs mandated their subjects to kill locust on their farms first before theirs. Chiefs as the heads of their communities had considerable power over decisions that touched on the socio-economic and political structure of the communities. There was a defined set of rules in matters of tributes from the people to their chiefs, giving the chieftaincy institution prestige in the communities. For example, a prescribed quantity of yams, maize, and other foodstuffs was provided by the head of a compound to the local chief to safeguard use rights over land for farming and maintain a cordial relationship that permits continual access to land. In this way, the Dagombas recognised the right of their chiefs, as caretakers of land on behalf of the community, who as allodial owners gave land to those who needed it to farming and development [35].

In the pre-colonial era, the hierarchy of subspontaneous tree species was from the african locust/dawadawa (Parkia biglobosa) to the shea (Vitellaria paradoxa), kapok (Ceiba pentandra) and the neem tree (Azadirachta indica). The fruits or seeds of all these trees were considered to be of great value and their collection and processing the subject of some competition [26]. These trees were relied on for different purposes; as a food spice, cooking oil, bathing soap, energy, stuffing for pillows, clothes and cream for the body. Women could access these four important economic trees only through the men in their lineages [28]. The sub chiefs owned the dawadawa, so one needed to obtain permission before it could be accessed. Blench [26] supported this assertion when he said that "in a few areas, major trees, such as dawadawa, belong not to the farmer but to the chief who has the right to harvest them and give a portion to the farmer."

The processing of dawadawa and shea were mainly in the hands of the women. These products were consumed in the household, and the surpluses sold, for the purchase of other household basic needs. Shea nuts were also processed and used as candles [31]. The shea butter trade existed long before colonialism in West Africa. Sutton [36] description of goods traded at the regional markets during the pre-colonial era states that "the amount of yams, cattle and shea butter passing south was directly related to the amount of salt going to north" through the trading links between the Sahelian kingdoms in the North and the Ashante kingdoms.

Apart from crop farming, the Dagomba's also reared livestock for many reasons; as sacrifices to the gods in demand for a request, annual rites to appease the earth god, for payment in exchange for farming services. During the rainy 
season, animals were enclosed, to avoid crop destruction as agriculture was mainly rain-fed. Their feeding and care were primarily in the hands of women and children. During the dry season, animals are allowed out of the pens to roam and feed. At this time ploughs were unknown, and animals were not used for farm work nor integrated into the farming economy [33].

Fynn [37] explained the events of the Ashante's invasion of the Northern territories in the mid- $16^{\text {th }}$ century by Opoku Ware (the grand-nephew of Osei Tu$\mathrm{tu}$ ), he listed the weaponry used by the Dagomba cavalry as traditional. They consisted of laces, spears, and sabres while Bowdich [38] mentions other weapons used like bows and arrows, javelin and clubs. These traditional weapons are labelled as one of the reasons why the Ashante defeated the Dagomba's due to the sophisticated and modern weapons they had like muskets. When the Dagombas were defeated, they became a vassal state of the Ashante's according to [35]. The defeat of the Dagomba cost them a yearly tax on slaves, cattle, sheep and cloth to the Ashantehene (King of the Ashante people). This invasion is also seen as the Ashante's way of securing labour for their gold mines and also to benefit from the market activities in the North at the time.

It is evident from the discussion above that agriculture was mainly rain-fed and the crops grown were mainly cereals, legumes, vegetables and tubers for subsistence. Shifting cultivation and bush fallowing was common, and the farms were cultivated with rudimental tools like hoes and cutlasses. Slash and burn farming was one of the primary means of preparing land for sowing a practice which is still being carried out today. Labour was produced mainly by the family, and usually, the male household head made all farm-related decisions. Women's subsistence activities relied on the decisions made by men on how to gain and maintain access to different resources like land, forest or trees. Here we see clearly how the identity of women are being constructed by male dominated institutions, who believe women should be subject to men and controlled in all they do. These constructions have structured the agricultural activities expected of men and women and significantly influence the agricultural system prevalent in Tamale. Men through norms have continually reshaped the productive and reproductive roles of women over time [28].

Although land was considered abundant and easily accessed through a chief or tindana, the notion of land abundance in Africa is being contested by [39]. [39], states that land was never abundant and that it has always been contested by different actors as they struggle to gain and maintain control over land. She explained that actors had used different strategies like the first comer's concept, tradition and power relations to legalise their claims over resources. Shifts in power relation over time and space between the chiefs and tindana have shaped resource access, as lands were now accessed mostly through chiefs and not tindanas who were stripped of their socio-political power and left only with spiritual powers over land purification and rituals. A different scenario is found in the Upper East, and Upper West regions were the tindana still has the same so- 
cio-political power as the chief and are in charge of land administration and management.

\subsection{Colonial Era}

The scramble for territories in the hinterland of the Gold Coast was between the French, British and Germans. The Germans had made contacts with chiefs in Savelugu, Yendi, Salaga, Gambaga, Karaga and Nanton who had accepted German protection according to [35]. This act by the Germans alarmed the British who had their eyes on Salaga, one of the leading trading routes in the North. They needed this area to be able to secure their commercial interest from the French. In 1899, after the Germans defeated the Dagomba at Aido and later destroyed Yendi. Britain and Germany decided to amicably come together and sign the Anglo-German treaty on $14^{\text {th }}$ November 1935, which partitioned the Dagomba area between these two countries as seen in Figure 2. The eastern part of

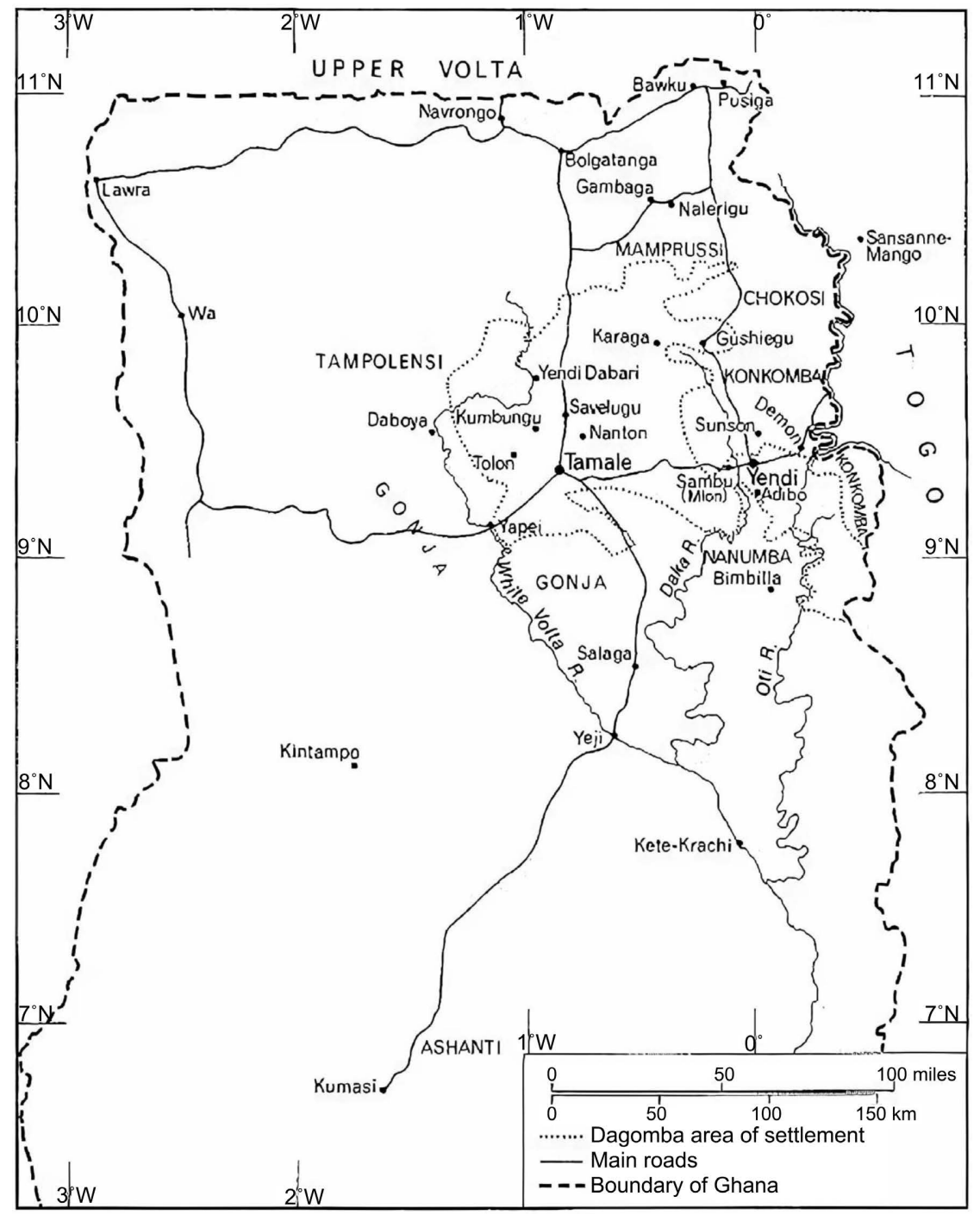

Figure 2. The partition of the Dagomba area. Source, [35]. 
Dagomba was controlled by the Germans and the Western section by the British. After the First World War when Germany was defeated the British took over the Dagomba area under German control in 1914 [40].

The Northern territories (present-day Northern Ghana) officially became a part of the British protectorate in 1902, after the defeat of the Germans. Sutton [25], describes the delayed acquisition of the Northern territories to a British Gold coast colony as an afterthought. After the annexation of the Northern territories to the Gold Coast, explorations were set in motion to find out the economic and political potential of this region to the Crown. George Ekem Ferguson, a Fante geologist, was employed by the Gold Coast government to make British annexation of the Northern territories legible. Ferguson reported that some resources such as gold and ivory could be found in this region, but that its greatest potential laid in agriculture. "Shea nut trees was widespread, rice and millet grew well in the plains, and the development of cotton, tobacco, and indigo" [25]. Caravan trading was flourishing at this time but more in the hands of outsiders like the Hausa, Fulani from further North and the Mossi from further South. The people of the Northern territories mostly sold their surpluses to the caravans and people transporting shea butter and yams going South in the Volta salt canoes, but mainly got their income from the extraction of tolls and market taxes from traders along this trading route [25].

The Northern territories were meant like all other colonies to provide raw materials for the European economy. The colony was expected to generate money to be used for running administrative cost and development projects [26]. Revenue collected by the colonial administrators derived from the caravan tolls and tax amounted to about 7000 - 15,852£ yearly in 1907 [25]. The goods taxed were usually livestock brought from the French colonies in the North, kola nut which came from Ashante, salt from Ada at the mouth of the Volta and a few manufactured goods from Togo and the colony. In 1908 with the abolition of the caravan tolls the revenue of the administration of the Northern territories dwindled to about $£ 2000$. The administrators had to rely on revenue from the sales of yam, shea butter, dawadawa and cotton which was not sufficient for the investment needed to improve sectors like transport, health, and education.

Staples constitute the backbone of the food economy of the Northern region according to Shaffer [41] and Fortes and Fortes [34]. They constitute the principle starchy food relied upon in the households and eaten with vegetable soup. These staple foods are provided by the men while the women provide the vegetable soup to be consumed with it. Staples are of particular importance during the "hunger months" that is, during the time of hoeing, planting, and weeding (April-June). This concept of "hunger month" is a phenomenon which is still present today in the Northern region [42]. The Fortes monthly compilation of agricultural activities depicts the hunger months or season in their account:

April: Food stores very low in average households and being rationed. Many households dependent upon supplementary sources of supply. Ample 
food supplies in market and many buying grain. Wild fruits...being consumed to starve off hunger.

May: Food stores deplenished and severe rationing. "Hunger" commences.

Poorer households suffer two or three days' hunger a week, living on vegetable soup, ground-nuts and wild fruits.

June: Peak of "hunger" reached. Granaries empty among poorer households...grain scarce and dear... Small groups of children wander about hungry, feeding on wild fruits and small animals...people are staunching their hunger by cutting the ripe or half ripe heads of early millet which they roast...

July: Wild fruit still eaten and hunger prevalent in late-planting areas... [34].

Locusts is known as the scourge of the earth symbolically in religious circles for example, when God punished the Egyptians with a plague of locust that ravished the land of all its harvest, in Exodus 10: 1-18, but are also delicacies amongst other societies [43]. In West Africa there exist two different locust species which have been recorded, the African migratory locust (Locusta migratoria miratorioides) and the desert locust (Schistocerca gregaria), with main breeding areas in the marshes of the central delta of the Niger River, Lake Chad area and the Sahara Desert respectively. These locusts are prone to ravaging cereals like bulrush millet (Pennisetum typhoideum), guinea-corn (Sorghum vulgare) and millet (Pennisetum spicatum) which are the main staple food for people in this guinea savannah zone.

Consequently, cereal producing communities were hard hit if the locust came when the crops were germinating or during the harvest [13]. Reports from 1910 to 1927 from archival material consulted by Weiss showed that trees also suffered from locust infestations even though the damage was minimal compared to cereals. Fruits trees were defoliated in the Tamale agricultural station and shea trees destroyed in Kusasi. The worst plagues of the migratory locust started in 1929 and continued for 10 years. These plagues caused extensive damage to the staple crops. Animals were sold to buy food, and large-scale emigration to the South was noted in some divisions like Lawra-Tuma. The chiefs solicited the help of the colonial government to get food from the South as hunger became widespread. The only sources of food available were tubers such as yams and cassava, and also rice which the locusts did not destroy.

Also, information collected from informal diaries of the different District Commissioners from Lawra and Bole paints a vivid image of these locust infestations. Some reports of destructions of cereal farms in Lawra-Tuma district area are listed in Table 1.

Other districts affected were the Western Dagomba district where the District Commissioner, Cardinall was horrified with hoppers were all over the district [13]. Here destructions of cereals farms were also reported. Farmers got tired of the locust destroying their crops and decided to stop sowing cereals as long as 
Table 1. Cereal farms destroyed by locust invasion in 1929.

\begin{tabular}{cccc}
\hline Data source & Date & Divisions & Farms destroyed \\
\hline Informal Diary Lawra & 16.11 .1929 & Sabule and Karui & 32 \\
Informal Diary Lawra & 28.11 .1929 & Sabule and Karui & 82 \\
Informal Diary Lawra & 19.11 .1929 & Zini & 47 \\
Informal Diary Lawra & 19.11 .1929 & Lambussie & 43 \\
Informal Diary Lawra & 19.11 .1929 & Hain & 33 \\
Informal Diary Lawra & 24.11 .1929 & Tuma area & 577 \\
\hline
\end{tabular}

Weiss [13].

the locust abound. The District Commissioner advised the chiefs to inform their communities to alternatively start growing yams and beans following food shortage and famine that plagued the district.

Around the late 1920's and 1930's, locust invasion coupled with adverse climatic conditions like erratic rainfall and poor soils led to reduced yields and subsequently increased widespread famine and hunger [13]. In the opinion of Grischow [44] even though food shortages in the Northern territories were reported every two years, nothing was technically being done by the colonial administration to alleviate this plight. After the First World War, to improve the welfare of the people, the Colonial Development Act of 1929 was introduced. This act promoted agriculture aimed at eradication of the tse tse fly which affected livestock especially cattle and promoted mixed farming [44]. It also facilitated the creation of a Nutrition Committee (NC) to examine the problem of malnutrition prevalent in this region [45].

The colonial administrators and native authorities from the different provinces met to discuss different strategies which could be adopted to survive the plight of the locust. Deliberations from these discussions centered on the cultivation of non-destructible hopper crops like yams and other root crops in the Southern and Northern Provinces. An embargo was placed on the exportation of guinea corn to the South, but the Dakpema reported cases of cereals being exported to the South illegally.

A relief fund to feed the population and provide them with seeds was carried out by the Native authorities in the Buipe area, and in the Savelugu division, about 700 loads of guinea corn was also provided by the Native authorities to be distributed. In the Northern Province, the District Commissioner opted for food for work programme, where all the men were employed to construct the $\mathrm{Na}$ vrongo-Zuarungu road in exchange for food. This project saw the employment of over 500 men until the end of the year. Weiss's [13] analysis of the locust invasion period in the Northern Territory brings to light aspects of governance between the chiefs and the colonial government. In this example, we see a co-construction of governance by the chiefs and colonist to solve problems of famine and hunger in these provinces, as they come together to deliberate and 
implement strategies agreed upon by all.

Even though relief policies were reached, one of the early difficulties was convincing farmers to start cultivating root crops, a practice they had not indulged in before, especially around the Navrongo area. The farmer's reason for not adopting this new policy in their words are "our fathers never grew them" according to information in the informal diary written on Navrongo community in 1930 cited in [13]. Here we see the farmers resisting change and governance policies by the colonist using historical recollections of their farming experiences and practices. The unavailability of digging sticks and enough seedlings also posed a challenge to this large scale project. This project to introduce root crop to farmers in the Navrongo area was later aborted.

[13] argued that this project was a "colonial propaganda" used to showcase colonial interventions in reducing famine and hunger, where more effective and efficient interventions could be done but were not done. This "colonial propaganda" led to increased yam cultivation in other areas like Wala, where changes in household food consumption were noticed. Yam consumption increased compared to that of other staples. Yam was prepared as the staple food to be eaten with the vegetable soup. The women also preferred yams preparation to maize, millet or guinea corn which was more labour intensive. Communal yam farms were developed in the Builsa Native administration and Lawra-Tuma district. The Dagombas who were already known to cultivate yams produced surpluses which were exported to Kumasi and Accra in the South. Here we see how governmental intervention by the colonial government has reshaped the agricultural practice of its subjects the farmers who diversified their crop production.

Rice was also given special attention by the colonial government for a while when they thought it could be a future cash crop, that will boost the economy of the Northern territories. Rice was chosen because it was not affected by the locust and had potentials of being a cash earner for the local farmers with the intend of reducing poverty and hunger, but also it was meant to provide funds for the colonial government if they operated large farms and exported it back home. This project partially succeeded as farmers started planting rice, but it did not attain the potentials for export. The traditional fast maturing guinea corn seeds from the Southern province known as red guinea corn or Kajie were also introduced in the Northern province, but little is said about the success of this particular project. Lynn, C. W. an agricultural Superintendent proposed alternatives and diverse crops like pigeon peas (Cajanus cajan), cassava (Manihot esculenta) and sesamum (Sesamum indicum) to remedy the food shortages caused by locust invasions.

Despite efforts put in place to promote the cultivation of alternative crops, some colonial agricultural experts like Shepard, C. Y, argued that the Northern territories is the most problematic part of the Gold Coast. Plagued by irregular rainfall, poor soils, bush fires, locust invasion and rinderpest epidemics which 
are detrimental to any agricultural activity. Shepard pointed out that another factor which slowed down agricultural growth was the conservative and somewhat primitive social organisation of the people (who refused to relocate from their villages to work on colonial farms because they did not want to leave the graves of their ancestors) contributing to food shortages in this region. This positioning of natives in the minds of the colonial administrators greatly differed, as some District Commissioners believed the natives could solve their own socio-economic problems with and without aid from the colonialist. This shift in the mindset of colonialist about the native's potentials contributed to the introduction of a more modern, technical and scientific approach to the economic crisis in the Northern Territories to improve the wellbeing of the people.

Sutton [25] states that sporadic attempts were made at generating a cash economy in the North as "experimental agricultural and livestock schemes were initiated, dropped and revived several times in the course of the colonial period". The changes introduced in the agricultural sector focused on soils and water conservation and also mixed farming-where animal husbandry was integrated with agriculture with the use of more manure. Experiments were carried out on existing crops found in this region like cotton, shea butter, grains, groundnut and also on livestock. Many reasons account for the failure of the different agricultural and livestock experiments. Each venture was treated as a new idea without reference to other past experiences. There was little or no coordination between the different organisations implementing these projects over time and space, leading to a waste of time, money and resources. The aim of the colonial council in reviving agriculture and exporting raw materials like cotton to Europe, livestock to the South did not yield any fruits. In this example, we see how governmental interventions with the aim to improve the livelihood of the masses as stated in [46], does not succeed, due to different interest and agendas by the actors.

The brief consideration of tobacco, dawadawa, rice, and shea butter as cash crops was problematic due to numerous factors. First, a good transport system was absent. Secondly, most the crops were not suited for mechanisation. Thirdly there was a lack of technical expertise to fix any machine that broke down. The British colonial government invested a lot in the experimentation with cotton as a possible cash crop. The British cotton association even introduced cotton hybrid seeds. Animal traction was introduced especially for this particular cash crop farming practice with ox-carts fabricated from wrecked cars, as the "main implement used is a heavy ridger pulled by paired oxen" [26]. These technologies were introduced first to chiefs, with the idea was that if the chiefs adopted these technologies, and then the people will do same. Chiefs, in this case, were used by the colonial administrators as an Obligatory Passage Point (OPP) to get the people enrolled in the project. New farm technologies were introduced to the chiefs by the colonists who believed that if chiefs adopted these technologies, other farmers would be convinced to adopt them too. This process of enrolment 
is a process through which an actor(s) convinces other actors to join his ideological network, by using discourses or intermediaries which the other actors accept. Even though the people did not adopt many technologies elaborated above, intercropping of maize and millet fertilised with manure collected from animal kraals close to the compound was adopted by many farmers [25].

Sutton [25] also discusses the large-scale groundnut farms opened in 1955 under the Gonja Development Company Scheme. The thinking behind this project was to acquire the land, plant, get farmers to weed it and when crops are sold, a third of the profit given to farmers. This project invested in the use of chemical fertilisers, tractors, and the crop rotation method. About 4000 acres of land was acquired, and expectations were to get roughly 400 farmers to settle and work on this farm. This project ended at the experimental phase with only 15 permanent farmers on site. Reasons for this failed project were that the farmers did not own the project, and found it taxing to relocate to this project farms to settle and farm. Apart from the intercropping example above, farmers resisted all other governmental interventions by the colonial government to change their agricultural system, in this way reshaping the governance system in place by not legalising their power and authority in controlling the agricultural system.

Irrigated dry season or market gardening on small protected plots was introduced by the Society of Missionaries of Africa (White Fathers) who grew vegetables around water bodies first in the upper East region as stated by [47]. The vegetables cultivated were mostly exotic that is, vegetables foreign to the local diet. Vegetable cultivation increased in the city as the colonial administrators each had gardens, where he or she cultivated vegetables and flowers for culinary and aesthetic purposes, especially in the Gold Coast [48]. In the North, vegetables were grown in compound and bush farms; these vegetables were grown in the wet season and dried for culinary use in the dry season. In a letter dated 12 April 1949, the Department of Agriculture requested that the District Commissioner hand over a vegetable garden in Choggu to an ex-service man Mr E. N. A. Boatey. This transfer was meant to facilitate the payment of rents for the land to the appropriate quarters (Ref No.0179/1). This shows that the local people also practiced dry season vegetable, but not on a large scale, compared to rain-fed vegetable agriculture which is a predominant practice because of the climatic condition in this agro-ecological zone.

In the livestock domain, cattle, sheep, goat, horses, donkeys, pigs and poultry of various types were kept by the Dagomba's. There were no intensive productions systems of animal rearing in the region, and small stocks were allowed to forage freely in the dry season and confined in the wet season [13]. Technological changes started in this sector with the importation of cattle from Europe with most of them dying before reaching the Gold Coast or shortly afterward. The few that survived were cross breed with the local cattle to produce what [25] referred to as half or quartered-bred European crosses, and they were placed in the 
chief's herds. This practice of passing down new technology to the community through the chiefs as already explained above was a popular concept then and sometimes still applied today in rural agricultural projects.

Later local selective stock breeding was encouraged, where Zebu, Mossi, and Ndama cattle were imported from Burkina Faso, Mali, Niger for cross breeding with the West African shorthorn cattle found in the protectorate [49]. This new breed of livestock from the French African colonies was given to chiefs of the Dagomba catchment area. Native authority kraals were thus created to increase the cattle population in the region, as old and dysfunctional bulls were replaced with new active bulls. A veterinary center was set up in Pong Tamale for the treatment of cattle. There existed few cattle-owning families who were not capitalist-oriented. Thus the objective of increasing cattle population for commercial purposes by the colonial administrators did not succeed [25].

From the pre-colonial to the colonial period Shaffer [41] argued that "by most accounts, agricultural practices in the 1930s were essentially unchanged from earlier times. The staple crops remained millet and guinea corn which were cultivated using the same techniques as in the earliest times". This is corroborated with an observation made by an agricultural officer Lynn, C. W, who describes agricultural activity thus, "men wander over the farm with long sticks and make holes at random, and women and children follow with the seeds in a calabash...the precarious food situation was due primarily to...methods not sufficiently intensive for the conditions obtaining" [50]. The quotation above reflects the contemporary agricultural practice of the Dagomba people, from my observation during fieldwork and even discussions with other colleagues who have interacted with farmers in peri-urban and rural areas. The slight difference is that few farmers now use tractors in their fields. [25] relates Gunder-Frank's metropole-satellite framework on Latin America, to the case of the Northern territories and the Gold Coast in Ghana. Gunder-Frank's framework in Figure 3 stated

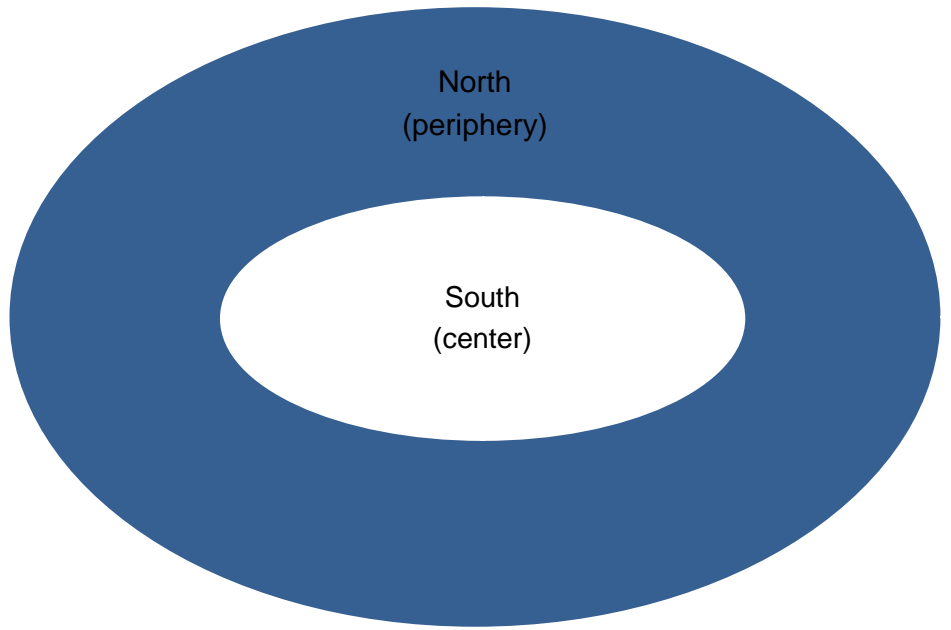

Figure 3. Center and periphery relationship between the Northern and Southern region in the Gold Coast (Author's construct, 2014). 
that metropolises were not only centers of confluence but exploitation, and he related this to the socio-economic and political relationship between the third world countries and the capitalist economies. The capitalist economies are meant to stay developed at the expense of the underdeveloped countries. Sutton uses the center-periphery relationship of Gunder-Frank to explain the relationship between the then Northern territories and the Gold Coast as designed by the British.

[25] stated that the North was a labour reserve for the South and its administration left at the mercy of the development in the South. This idea of the North being a labour reserve for industries and plantations in the South is supported by many authors like [51] [52]. [13] also supports this idea when he stated that the work for food programme and the use of compulsory labour retarded development in the North in favour of the South. Also, cheap food and reasonable prices for labour rendered in the South also encouraged North-South migration in the Gold Coast colony. Southern development was essential to the European economies, so labour from the North was solicited to boost the Southern economy through mineral extraction, oil palm exports and rails constructions [26]. This, altered the North's position as a food supplier to the South and crippled little of what was left of its economy. The colonial government's opinion on the North-South divide was evident from some of their statements;

I cannot too strongly urge the employment of all the available resources of the Government upon the development of the country south of Kintampo...I would not at present spend upon the Northern Territories-upon in fact the hinterland of the Colony-a single penny more than is absolutely necessary for their suitable administration and the encouragement of the transit trade...until the Colony and Ashanti have been thoroughly opened up and developed, the Northern Territories must be content to await their turn [53].

In this section, I have discussed the emergence of a semi-mechanised (use of animal traction) agricultural system based on mixed farming and improved livestock rearing which was introduced during the colonial period. These factors had little or no effect on long-established norms of agriculture when it came to-land allocation, labour distribution, and agriculture output. This was because land allocation was mainly in the hands of the chiefs, who still controlled agricultural resources supervised by the colonial administration. The agricultural system can be said to have changed only slightly with the adoption of improved hybrid and pollinated seeds by commercial and smallholder farmers through projects participation. Many of the agricultural and livestock innovations either died at the experimental phase or after subsidies attached to the projects came to an end. The colonist's strategy of using the chiefs as intermediaries to convince farmers in the community to adopt these new technological packages did not work as chiefs were not interested in these projects. 
Furthermore, some of the District Commissioners resorted to the use of unpaid labour for road construction, government buildings and courier services causing many young men to flee to the South where they were sure of payment for labour services. By resisting the governance system in the North and moving to the South, the people fitted into the global British governance system in their colonies which was economically oriented. This migration trend hurt the agricultural sector in the North but a reverse situation in the South. Thus, interactions between British Governors in the North and South to promote British interest were fulfilled, at the expense of Northern development.

The social structure of the family also changed significantly, as many women became family heads in the absence of their husbands, who had migrated to the South. Women, in this case, took daily decisions, which were supervised by their male kins who had not moved down South. This situation did not give them direct access to resources such as land. Food was mainly bought by the men who went to work in the South to feed their families. This probably contributed to the Dagomba culture where women are primarily involved in marketing and men in farming. Women continued processing shea nut and dawadawa for spice, food, and cosmetics, as a survival strategy and source of livelihood for the family. In the next section, I will examine if any recent changes have altered the agricultural system with the introduction of projects by many multilateral organisations, and if this has reshaped resource access and control in any way.

\subsection{Post-Colonial Era}

After independence in 1957, the new government realised that the economy of the country had to move at a fast pace to catch up with the rest of the world. Representatives from the Northern territories had demanded a speedy economic and social development to catch up with the rest of the country. They wanted roads, schools and other basic socio-economic amenities and services. This view by representatives of the Northern territories reflected those of many colonial administrators. [25] and [54], argued that the lack of a proper transport system and other social amenities impeded any agricultural improvement or development as a whole in the Northern part of Ghana. In the opinion of [55] the agricultural policy in the 60' had shifted from a capitalist ideology to a socialist one under Nkrumah, where vast tracts of government managed farms and cooperatives were opened subsidies in the form of fertilisers, tractors and improved seeds made available for agricultural production in the North. The Agricultural Development Corporation (ADC) was created then to spearhead this agricultural moderniation and to exploit the economic opportunities at that time.

As stated in [56] and [26] from 1964 to 70's, with the overthrow of Nkrumah, a military regime took over and changed the agricultural system from socialist ideologies to a capitalist ideology, with calls for more investments in commercial food production. Cooperatives, private-led rice investments, and cotton farms were promoted. The Agricultural Development Bank (ADB) was enacted to 
support and provide needed credit to promote agriculture through an Act of Parliament (Act 286) in 1965 under the name of the Agricultural Credit and Cooperative Bank. This credit facility was mostly accessed by literate community members who were able to obtain the necessary documents needed to guarantee bank loans and get a written registration of land holdings. This governance technique was used by the state as a mechanism to control access to land and other resources for farming. This technique excluded poor community farmers, who could not gain access to these credits nor get registered land holdings.

The acquisition of large mechanised private farms led to the creation of a new group of farmers known as urban-based capitalist farmers who were different from communal farmers, as most of them were civil servant personnel, private investors and ex-military [57]. They were more interested in commercial cash crop cultivation and had an entrepreneurial spirit. Their easy access to credit, loans, and land holdings created resentment amongst the indigenes because they could not benefit from this system of farming since they did not have the money or connections to get loans and guarantee land holdings. Moreover, as stated above, this method of acquiring land was in competition with the local people procedure of having access to land. Villagers rebelled against this form of land acquisition by destroying machinery on the farms and burning the rice fields [57] [58]. This goes to solidify previous discussions that governmental interventions are not always accepted by subjects but are sometimes resisted, creating multiple governance systems. Indigenes, in this case, used the traditional norms on land acquisition to fight against the commercial agricultural system in place, thereby legitimising the traditional governance system. [26] was also of the opinion that "similar attempt to develop large-scale mechanised farming would be subject to similar problems", in any near future. He also warned that state intervention on land administration and management could easily lead to the individualisation of lands, a phenomenon which is now widespread in urban and peri-urban Tamale.

Muslim migrants such as the Zarma and the Hausa were presumed by [26] to be one of the first people to practice horticulture in riparian areas in the Northern region, even though he does not specify the year this activity started. The white fathers also practiced vegetable gardening along water bodies and around shallow rivers. This practice became more predominant in the dry season, a time when not much agricultural work was done. This is because agriculture is a predominantly rain-fed activity usually carried out for only 120 days a year in this region according to [59], with gardens mostly found at the edges of dugouts used for agricultural and domestic purposes.

In the early 1970's the capitalist ideology was pushed aside and a semi-socialist or "nationalistic" system taken up by the Acheampong's regime. [48] mentioned that during this regime, due to the economic crisis and famine the "Operation feed yourself" programme was launched. This programme was introduced as a result of high inflation and scarcity of basic commodities-as a result of political 
upheavals and droughts in the country. The country had large external loans which were yet unpaid, to salvage the economy Acheampong instituted the yentua policy (we shall not pay) and the international community responded by cutting all external credit and aid to Ghana. This resulted in food shortages exacerbated by the 1983 droughts. This programme legitimised interstitial farming in the city with no fear of crops destructions, as the bylaws on urban agriculture were relaxed to increase food supply in the community [60]. This programme permitted urban agriculture for everyone and not just for the government administrators as was the case during British colonial rule, where only colonial administrators were allowed to practice urban farming. From the discussion above, political interest and international relations have a direct effect on the socio-economic environment of a country and indirectly its agricultural system.

Urban dwellers got involved in patch agriculture as a source of survival and also as a source of secondary income. During this time smallholder farmer were favoured in comparison with large scale farms owners. Most of the nationalized farms introduced by Nkrumah had fallen apart [55] [61]. Urban agriculture in the city grew during this time as opposed to the colonial era where city planning did not permit urban agriculture for everyone due to health and hygiene reasons [48].

The data presented in Table 2, was collected in 1966 by [48], in Accra to find out when people started getting involved in urban agriculture. The number of individuals interviewed and sampling method used in collecting the data is not mentioned. The above table is just a reflection of the history of urban agricultural practices in changing political times. From the table, a rise in urban agriculture can be seen from 1966-1975, during the operation "feed yourself programme" introduced by Acheampong, when Ghanaians were encouraged to grow food and feed themselves. This practice declined during Rawlings military rule in Ghana when droughts and famine took over the country. The reason for this decline in urban agriculture could be due to government agricultural policy and intervention which focused on rural than urban areas. Even though urban farming is still being practiced in the Ghanaian society and in many West African cities, it has not been integrated into the planning schemes in the towns and its considered illegal except in few countries like Tanzania, Uganda, and Kenya according to [62].

Table 2. An urban farming survey carried out in Accra.

\begin{tabular}{ccc}
\hline Cultivation period & Frequency & Percentage \\
\hline Before 1966 & 20 & 10 \\
$1966-1975$ & 67 & 33.5 \\
$1975-1985$ & 55 & 27.5 \\
$1986-1995$ & 58 & 29 \\
Total & 200 & 100.0 \\
\hline
\end{tabular}

Source: [48]. 
In the 1990's donkey carts were introduced from neighbouring Burkina Faso to aid farmers in transporting manure, compost and tools to farms and later food to markets for sale. Even though donkey carts were very useful to farmers, the prices for these carts remained a main financial obstacle for many farming families [14]. When these carts developed faults, they were often abandoned due to the lack of technical expertise in the region to work on it, so many farmers did not adopt this technology. Farmers presently using donkey carts are the wealthier farmers. Tractors were available as subsidies flowed in but with the end of these subsidies only a few wealthy farmers had tractors which they hired out to other farmers at the start of the planting season [26]. From the above information, governmental interventions were sometimes not accepted by the subjects not because they were not good, but sometimes due to other socio-economic factors like the lack of finance to acquire and maintain these resources.

The post-colonial period saw a lot of investment by multilateral and international agencies in rice and maize cultivation-in irrigation sites and natural floodplains [26]. Socio-economic and political policies like the Poverty Reduction Strategy (PRS) which is an extension of the Structural Adjustment Programme (SAP) was introduced by the government and facilitated by the World Bank (WB) and International Monetary Fund (IMF). Even though these policies were put in place to improve the failing economy of the country, the reduction of subsidies contributed to the lapse in agricultural development and research [63] [64]. Agricultural projects did not all cease, as several initiatives on smallholder projects on crop cultivation and livestock were launched by international agencies such as the Food and Agricultural Organisation (FAO) and later the International Fund for Agricultural Development (IFAD). These projects were mostly carried out by local non-governmental organisations in collaboration with the Ministry of Agriculture sometimes in what [65] refers to as trans-governmental interventions or transnational governmentality.

According to [26], a Northern Region Integrated Project was also conceived to take an integrated approach to planning and agricultural development in the Northern region even though it did not achieve much. The World Bank initiated a National Livestock Services Project (NLSP) in 1993 to improve veterinary care through the construction of communal water holes and inducted the use of improved pastures. Non-Governmental organisations (NGO's) like Save the Children Fund, the Adventist Development and Relief Association and ActionAid were and are important players in the agricultural system in this region, where government contributions are not significant as mentioned in the [66]. Many of these projects by international development agencies are carried out to legitimise their authority in this country and status in the development arena.

I have discussed how different political regimes addressed agricultural activities especially vegetable cultivation. It was clear that urban agriculture became widespread as a result of governmental interventions which encouraged it and declined when the agricultural policies changed. Food production and consump- 
tions patterns in this region have changed significantly due to the adoption of different technological packages from various national and international NGO's. Many of such technological packages were agricultural inputs such as improved seeds, fertilisers, and tractors. Recent technological packages introduced in the horticultural sector are, drip irrigation in Sakpehalegu and Gumbihini old dam site, solar irrigation panel in Fooshegu and Daitoyili, organic compost and improved seed varieties in Gumbihini, Ganasco dam, and many other sites. These technologies are changing the pattern of vegetable production and consumption in this region, especially in Tamale as more middle-income urban dwellers are consuming more vegetables than before. A mixed farming system is now practiced in which livestock owners use manure from their animals to fertilise their fields and those who do not keep animals, buy or secure freely chicken droppings to use for their vegetable gardening like in Sangani. According to a focus group discussion in 2014, I was informed that farm inputs like fertilisers, water pumps are mostly used by farmers when they come at a subsidised rate. This is the case with water pumps used by farmers in Tuunayili. The end to subsidies for water pumps and fertiliser has forced farmers to look for cheaper alternatives, through visiting researchers like me.

Lands for compound and bush farms are still accessed by obtaining usufruct rights from chiefs. Men are still in control of access to land and rely heavily on household labour on their farms. A new trend of hired labour was observed on government irrigation sites where women are recruited to harvest vegetables in exchange for money or sometimes the harvested vegetables as discussed in [28]. Farming in the North is no longer subsistence but its semi-subsistence as many governmental interventions even though not well linked has led to changes in the agricultural practice in this region. These variations in the agricultural sector have legitimised development projects carried out by national organisations with foreign aid and also resulted in co-constructions of governance systems as subjects accept and resist governmental interventions. The shift in political ideology from socialist to capitalist camp and vice versa has over the years affected the agricultural system of Ghana, as can be seen in the different governmental interventions during these different political regimes and has slowed agricultural progress especially in this region. The emergence of vegetable farming and its management in the advent of urbanisation and increasing population growth is crucial to the revitalization of agriculture in northern Ghana.

\section{Conclusions}

I have examined how shifting power relations between the tindanas and chiefs have changed rules in gaining access and maintaining control over resources, and how this has restructured the agricultural system. This shift in power relations has also structured labour relations in the family and society, as subjects were automatically expected to work in the fields of the chiefs for free while taking care of their own fields. 
Different political regimes have over the years enacted different techniques in the form of policies, programmes and projects through which they have governed the people from afar. These projects, programmes, and policies were meant to reshape the agricultural practices of the people from a subsistence system to a more mechanised or industrial system. These governmental interventions were sometimes accepted and resisted by the subjects, creating new or sometimes hybrid governance systems. Most of these projects and programmes as explained above were meant to serve the interest of the intervener and also position them as credible and fundable organisations in the development world.

In addition, changing agricultural policy has also influenced practice of urban agriculture in Ghana. The practice of urban agriculture is used by non-governmental organisations to legalise their activities which are embedded in the idea of food and nutritional security. Due to the high rate of poverty and food insecurity in Northern Ghana, agricultural projects, and programmes are always embraced by the state and sanctioned to take place even though these projects are generally not linked as interveners compete against each other.

Each venture was treated as a new idea without reference to other past experiences. There was little or no coordination between the different organisations implementing these projects over time and space. We conclude that our agricultural systems can be improved if policies are inclusive, equitable and sustainable and also if there are synergies between international or government organisations implementing agricultural projects over time and space.

\section{Author Contributions}

The article is part of the $\mathrm{PhD}$ work of the first author. The paper was conceptualised by the first author and co-written by all authors.

\section{Acknowledgements}

This work was carried out in the context of the Urban Foodplus Project, "African-German partnership to enhance resource use efficiency and improve food security in urban and peri-urban agriculture of West African cities" funded by the German Federal Ministry of Education and Research under the initiative GlobE-Research for the Global Food Supply, grant number 031A242 C. I will like to thank all vegetable farmers, key government informants, non-governmental organisations and research institutions in the study area for their understanding and cooperation during the data collection phase.

\section{Conflicts of Interest}

There is no conflict of interest.

\section{References}

[1] Bjornlund, V., Bjornlund, H. and Van Rooyen, A.F. (2020) Why Agricultural Production in Sub-Saharan Africa Remains Low Compared to the Rest of the 
World-A Historical Perspective. International Journal of Water Resources Development, 36, S20-S53. https://doi.org/10.1080/07900627.2020.1739512

[2] Austin, G. (2015) The Economics of Colonialism in Africa. In: The Oxford Handbook of Africa and Economics, Oxford University Press, Oxford, 522-535. https://doi.org/10.1093/oxfordhb/9780199687114.013.4

[3] Logan, F. (2015) Did Structural Adjustment Programmes Assist African Development? E-International Relations Students.

https://www.e-ir.info/2015/01/13/did-structural-adjustment-programmes-assist-afri can-development

[4] Tsikata, D. (1995) Effects of Structural Adjustment on Women and the Poor. Third World Resurgence, 61, 1-8. https://www.twn.my/title/adjus-cn.htm

[5] Fatton, R. (1992) Predatory Rule: State and Civil Society in Africa. Lynne Rienner, London.

[6] Clapham, C. (1996) Africa and the International System: The Politics of State Survival. Cambridge University Press, Cambridge.

[7] Terry, S. (2019) International Monetary Fund Structural Adjustment Policy and Loan Conditionality in Ghana: Economic, Cultural, and Political Impacts. UVM Honors College Senior Theses. 319. https://scholarworks.uvm.edu/hcoltheses/319

[8] Whitfield, L. (2009) The New "New Poverty Agenda" in Ghana: What Impact? (No. 2009: 15) DIIS Working Paper.

[9] Whitfield, L. (2010) The State Elite, PRSPs and Policy Implementation in Aid-Dependent Ghana. Third World Quarterly, 31, 721-737. https://doi.org/10.1080/01436597.2010.502692

[10] Domfeh, K.A. and Bawole, J.N. (2009) Localising and Sustaining Poverty Reduction: Experiences from Ghana. Management of Environmental Quality: An International Journal, 20, 490-505.

[11] Carr, E. (2008) Rethinking Poverty Alleviation: A “Poverties" Approach. Development in Practice, 18, 726-734. https://doi.org/10.1080/09614520802386363

[12] Kolavalli, S., Flaherty, K., Al-Hassan, R. and Baah, K.O. (2010) Do Comprehensive Africa Agriculture Development Program (CAADP) Processes Make a Difference to Country Commitments to Develop Agriculture? The Case of Ghana.

[13] Weiss, H. (2004) Locust Invasions in Colonial Northern Ghana. WOPAG Working Paper on Ghana: Historical and Contemporary Studies 3.

[14] Blench, R. and Dendo, M. (2007) Working Paper: Agricultural Production and the Potential for Commodity Chain Expansion in the Three Northern Regions of Ghana in 2006.

[15] Namara, R.E., Horowitz, L., Nyamadi, B. and Barry, B. (2011) Irrigation Development in Ghana: Past Experiences, Emerging Opportunities, and Future Directions: Ghana Strategy Support Program (GSSP). GSSP Working Paper No. 0027.

[16] Ghana Statistical Service (2013) 2010 Population and Housing Census: Regional Analytical Report, Northern Region.

[17] Imam, H.A. (2015) State and Non-State Actors in Land Appropriation: Colonial Land Policy and the Role of the Tindana in Northern Ghana. Research on Humanities and Social Sciences, 5, 126-140.

[18] Mahama, I. (2003) Ethnic Conflicts in Northern Ghana, Tamale: Cyber Systems.

[19] Tait, D. (1955) History and Social Organisation. Transactions of the Gold Coast \& Togoland Historical Society. Historical Society of Ghana, 1, 193-210. 
http://www.jstor.org/stable/41406592

[20] Cardinall, A.W. and Tamakloe, E.F. (1931) Tales Told in Togoland and Mythical and Traditional History of the Dagomba. Oxford University Press, London.

[21] Talton, B. (2010) Politics of Social Change in Ghana: The Konkomba Struggle for Political Equality. Palgrave MacMillan, New York. https://doi.org/10.1057/9780230102330

[22] Niñez, V.K. (1984) Household Gardens: Theoretical Considerations on an Old Survival Strategy: Potatoes in Food Systems Research Series Report No. 1. International Potato Center.

https://books.google.de/books?hl=en\&lr=lang en\&id=JiLX1IeMoi0C\&oi=fnd\&pg= PA5\&dq=Nine,$+\mathrm{V}+\mathrm{K}+1984+$ household + gardens\&ots $=J 4 \mathrm{Cs} 0 \mathrm{DAq}$ 0m\&sig $=\mathrm{RSpTS}$

$\underline{\mathrm{X}} \mathrm{g}$ W7nJq-C23auiF $\mathrm{mLpc} \# \mathrm{v}=$ onepage $\& \mathrm{q} \& \mathrm{f}=$ false

[23] Kranjac-Berisavljevic, G. and Gandaa, B.Z. (2004) Sustaining Diversity of Yams in Northern Ghana. In: Gyasi, E.A., Kranjac-Berisavljevic, G., Blay, E.T. and Oduro, W., Eds., Managing Agrodiversity the Traditional Way. Lessons from West Africa in Sustainable Use of Biodiversity and Related Natural Resources, United Nations University Press, New York, 84-96.

[24] McIntyre, B.D. (2009) Global Report. Island Press, Washington DC.

[25] Sutton, I. (1989) Colonial Agricultural Policy: The Non-Development of the Northern Territories of the Gold Coast. The International Journal of African Historical Studies, 22, 637. https://doi.org/10.2307/219058

[26] Blench, R.M. (1999) Agriculture and the Environment in Northeastern Ghana: A Comparison of High and Medium Population Density Areas. In: Blench, R.M., Ed., Natural Resource Management and Socio-Economic Factors in Ghana, Overseas Development Institute, London, 21-43.

[27] Yaro, J.A. (2010) Customary Tenure Systems under Siege: Contemporary Access to Land in Northern Ghana. GeoJournal, 75, 199-214.

https://doi.org/10.1007/s10708-009-9301-x

[28] Nchanji, E.B. and Bellwood-Howard, I. (2016) Traditional Provisional Responsibilities of Women in Northern Ghana. In: Demos, V. and Segal, M., Eds., Gender and Food. From Production to Consumption and after, Emerald Group Publ., London, 41-64. https://doi.org/10.1108/S1529-212620160000022013

[29] Benneh, G. (1968) Types of Farm Labour in Northern Ghana. Research Review, 4, 28-34.

[30] Goody, J. and Buckley, J. (1973) Inheritance and Women's Labour in Africa. Africa, 43, 108-121. https://doi.org/10.2307/1159323

[31] Musah, A. (2013) It Is Not All about Reproductive Labour: Excluded Traditional Ventures and Rural Livelihoods among Women in Northern Ghana. Research on Humanities and Social Sciences, 3, 128-136.

[32] Tengan, A.B. (2000) Hoe-Farming and Social Relations among the Dagara of Northwestern Ghana and Southwestern Burkina Faso. Peter Lang, Frankfurt am Main, New York.

[33] Dickson, K.B. (1969) The Historical Geography of Ghana. Cambridge University Press, London.

[34] Fortes, M. and Fortes, S.L. (1936) Food in the Domestic Economy of the Tallensi. Africa, 9, 237-276. https://doi.org/10.2307/1155627

[35] Staniland, M. (1975) The Lions of Dagbon: Political Change in Northern Ghana. Cambridge University Press, Cambridge. 
https://doi.org/10.1017/CBO9780511759543

[36] Sutton, I.B. (1981) The Volta River Salt Trade: The Survival of an Indigenous Industry. Journal of African History, 22, 43-61. https://doi.org/10.1017/S0021853700019009

[37] Fynn, J.K. (1971) Asante and Its Neighbours, 1700-1807. Longman; Northwestern University Press, Harlow.

[38] Bowdich, T.E. (1819) Mission from Cape Coast to Ashantee. J. Murray, London.

[39] Lentz, C. (2013) Land, Mobility, and Belonging in West Africa. Indiana University Press, Bloomington.

[40] Owusu-Ansah, D. (2014) Historical Dictionary of Ghana. Rowman and Littlefield, Lanham.

[41] Shaffer, P. (2015) Colonialism and Seasonal Poverty in the Northern Territories of the Gold Coast, Circa 1900-1940. Q-Squared Working Paper 1-18.

[42] Apusigah, A.A. (2009) The Gendered Politics of Farm Household Production and the Shaping of Women's Livelihoods in Northern Ghana. Feminist Africa, 12, 51-68.

[43] Obeng-Ofori, D., Torto, B., Njagi, P.G.N., Hassanali, A. and Amiani, H. (1994) Fecal Volatiles as Part of the Aggregation Pheromone Complex of the Desert Locust, Schistocerca gregaria (Forskal) (Orthoptera: Acirdidae). Journal of Chemical Ecology, 20, 2077-2087. https://doi.org/10.1007/BF02066244

[44] Grischow, J. (2006) Shaping Tradition: Civil Society, Community and Development in Colonial Northern Ghana 1899-1957. Brill Academic, Leiden.

https://doi.org/10.1163/9789047410232

[45] Worboys, M. (1988) The Discovery of Colonial Malnutrition Between the Wars. In: Arnold, D., Ed., Imperial Medicine and Indigenous Societies, Manchester University Press, Manchester, 208-255.

[46] Li, T.M. (2007) The Will to Improve: Governmentality, Development, and the Practice of Politics. Duke University Press, Durham. https://doi.org/10.1515/9780822389781

[47] Wardell, A. and Fold, N. (2013) Globalisations in a Nutshell: Historical Perspectives on the Changing Governance of the Shea Commodity Chain in Northern Ghana. International Journal of the Commons, 7, 367-405. https://doi.org/10.18352/ijc.361

[48] Obusu-Mensah, K. (2002) Changes in Official Attitudes towards Urban Agriculture in Accra. African Studies Quarterly, 6, 19-32.

[49] Mahama, I. (2009) A Colonial History of Northern Ghana. GILLBT Printing Press, Tamale.

[50] Lynn, C. (1942) Agriculture in North Mamprusi: A Review of a Decade's Progress. Farm and Forest, 3, 78-83.

[51] Nii-K, P. (2007) Underdevelopment in Northern Ghana: Natural Causes or Colonial Capitalism? Review of African Political Economy, 6, 4-14. https://doi.org/10.1080/03056247908703393

[52] Ladouceur, P.A. (1979) Chiefs and Politicians: The Politics of Regionalism in Northern Ghana. Longman, London.

[53] Kimble, D. (1963) A Political History of Ghana: The Rise of Gold Coast Nationalism, 1850-1928. Oxford at the Clarendon Press, London.

[54] Brukum, N.J.K. (1997) The Northern Territories of the Gold Coast under British Colonial Rule, 1897-1956: A Study in Political Change. National Library of Canada, 
Ottawa.

[55] Asuming-Brempong, S. and Kuwornu, J.K.M. (2013) Policy Initiatives and Agricultural Performance in Post-Independent Ghana. Journal of Social and Development Sciences, 4, 425-434. https://doi.org/10.22610/jsds.v4i9.781

[56] Ouma, S. (2015) Assembling Export Markets: The Making and Unmaking of Global Food Connections in West Africa. John Wiley \& Son, Hoboken. https://doi.org/10.1002/9781118632567

[57] Goody, J. (2007) Rice-Burning and the Green Revolution in Northern Ghana. Journal of Development Studies, 16, 136-155. https://doi.org/10.1080/00220388008421752

[58] Konings, P. (1984) Capitalist Rice Farming and Land Allocation in Northern Ghana. The Journal of Legal Pluralism and Unofficial Law, 16, 89-119. https://doi.org/10.1080/07329113.1984.10756284

[59] Gyasi, E.A., Fosu, M., Kranjac-Berisavljevic, G., Mensah, A.M., Obeng, F., Yiran, G.A.B., et al. (2014) Building Urban Resilience: Assessing Urban and Peri-Urban Agriculture in Tamale, Ghana. United Nations Environment Programme (UNEP), Nairobi.

[60] Asomani-Boateng, R. (2002) Urban Cultivation in Accra: An Examination of the Nature, Practices, Problems, Potentials and Urban Planning Implications. Habitat International, 26, 591-607. https://doi.org/10.1016/S0197-3975(02)00027-9

[61] Miller, B. (2015) Food and Nationalism in an Independent Ghana. Thesis, Georgia State University. https://scholarworks.gsu.edu/history theses/93

[62] Lee-Smith, D. (2010) Cities Feeding People: An Update on Urban Agriculture in Equatorial Africa. Environment and Urbanization, 22, 483-499. https://doi.org/10.1177/0956247810377383

[63] Lipton, M. and Ahmed, I. (1997) Impact of Structural Adjustment on Sustainable Rural Livelihoods: A Review of the Literature. IDS Working Paper 62, 1-33.

[64] Briggs, J. and Yeboah, I.E. (2001) Structural Adjustment and the Contemporary Sub-Saharan African City. Area, 33, 18-26. https://doi.org/10.1111/1475-4762.00004

[65] Ferguson, J. and Gupta, A. (2002) Spatializing States: Toward an Ethnography of Neoliberal Governmentality. American Ethnologist, 29, 981-1002. https://doi.org/10.1525/ae.2002.29.4.981

[66] World Development Report (2006) Bridging the North South Divide in Ghana: Draft Summary: Background Papers. Equity \& Development. 